International Journal of Biological Research, 2 (2) (2014) 87-89
International Journal of Biological Research
Journal home page: $\begin{gathered}\text { www.sciencepubco.com/index.php/IJBR } \\ \text { doi: } 10.14419 / \text { ijbr.v2i2.3161 } \\ \text { Research Paper }\end{gathered}$

\title{
Administration of counterfeit sildenafil citrate to Wistar rats: impact on serum micronutrient levels
}

\author{
Ayobola Abolape Iyanda, Dapo Pius Oparinde* \\ Department of Chemical Pathology, College of Health Sciences, Ladoke Akintola University of Technology, Osogbo, Nigeria \\ *Corresponding author E-mail: dpoparinde@lautech.edu.ng
}

\begin{abstract}
Background: Counterfeit drugs have been recognized as a cause of many pathologic states, sometimes resulting in death. Even when their exposure does not lead to death, there is still the possibility of slight alteration in many physiologic processes in the body; namely digestion, absorption and homeostatic mechanisms.

Objective: The objective of the study is to determine the impact of counterfeit sildenafil citrate on serum micronutrient levels in male Wistar rats. Method: Twenty-one rats $(250 \mathrm{~g})$ were randomly distributed equally into 3 groups. The first, second and third groups were administered with $25 \mathrm{mg} / \mathrm{kg}$ BW of fake sildenafil citrate, $25 \mathrm{mg} / \mathrm{kg}$ BW genuine sildenafil citrate and distilled water (control) respectively. The route of administration was by gastric gavage. The serum concentrations of trace elements and vitamins were estimated using the Atomic Absorption Spectrometry and High Performance Liquid Chromatography respectively. Statistical analysis of data was carried out by using analysis of variance. A p value of $\leq 0.05$ was considered significant.

Results: Results revealed that all the micronutrients were significantly different except thiamine, niacin, vitamin B12, Mn, Fe, Cr, Mo, Co, riboflavin, pyridoxine, pantothenic and vitamin D. All the animals survived till the end of the study.

Conclusion: The implication of the results is that while fake drug exposure may not result in death, it may cause depletions in various micronutrients known for their vital roles in the body.
\end{abstract}

Keywords: Fake Drug; Minerals; Vitamins; Sildenafil Citrate.

\section{Introduction}

According to Jackson et al. (Jackson et al. 2012) counterfeit medicines pose an ever-increasing threat to public health. Although the present study is concerned with evaluating the impact of fake sildenafil citrate on serum micronutrient levels in male rats, available data have shown that all categories of medications have been targeted by counterfeiters (Gautam et al. 2009). This is more so in the developing countries, but since the internet has also provided a vast and convenient route for counterfeit drug to get to potential buyers, the developed world also has not been left out, in the menace of counterfeit medicines (Gautam et al. 2009). Marketing survey of more than 5000 consumers across five European countries have shown that as many as 12.8 million consumers may be exposed to counterfeit drugs in those markets yearly.

The World Health Organization (WHO) has defined counterfeit medications as drugs that are 'deliberately and fraudulently mislabelled with respect to identity and/or source. Counterfeit products may include products with the correct ingredients or with the wrong ingredients, without active ingredients, with insufficient active ingredient(s) or with fake packaging' (WHO, 2006). Jackson et al. (2012) revealed that some of these fake medicines lack the purported drug compound, have different concentrations of active ingredients or sometimes contain dangerous toxins. On the other hand, WHO also recognized that some tested counterfeit medications have been found to contain excessive amounts of active ingredients or wrong ingredients (Mali et al. 2011) the effects of which may be harmful. A myriad of adverse health ef fects, even death have been associated with the use of counterfeit medications.

Although many studies have revealed a variety of reasons why there is wide availability of fake drugs, according to Jackson et al. (2012) consumers who self-medicate without appropriate interactions with the healthcare system are those most frequently affected? The effects of counterfeit drug come in different forms and severity and it is not impossible that a counterfeit drug is capable of altering the serum status of many biomolecules. Micronutrients are important elements and biomolecules known for their very vital functions in maintaining health. They are highly essential in sustaining life and development through the roles they play in many biochemical reactions. The main objective of this study is to determine the impact of fake sildenafil citrate on serum micronutrient levels in male Wistar rats.

\section{2. . Materials and methods}

\subsection{Experimental animals and animal treatment}

Male Wistar rats of average weight of $250 \mathrm{~g}$ were utilized for the study, which was carried out in accordance with national and international laws and Guidelines for Care and Use of Laboratory Animals in Biomedical Research Institutes of Health (revised 1985). They were purchased from and kept at the Experimental Animal Unit of Faculty of Veterinary Medicine, University of Ibadan, Nigeria. The rats were kept in cages at ambient temperature of $26 \pm 3^{\circ} \mathrm{C}$ and a $12 \mathrm{~h}$ light, $12 \mathrm{~h}$ dark cycle and were supplied 
water and laboratory chow ad libitum. The study period lasted 7 days. The rats were divided into 3 groups comprising of 7 rats per group. The first group of rats was dosed with $25 \mathrm{mg} / \mathrm{kg} \mathrm{BW}$ of fake sildenafil citrate while those in the second group received 25 $\mathrm{mg} / \mathrm{kg} \mathrm{BW}$ genuine sildenafil citrate (Fibbi et al. 2008). The third group of rats were administered with distilled water and served as control. The route of administration was by gastric gavage for all the rats in the 3 groups. While the genuine sildenafil citrate was purchased from a pharmaceutical store, fake sildenafil citrate was obtained from National Agency for Food and Drug Administration and Control (NAFDAC), Western region office in Ibadan. The blood was collected through retro-orbital bleeding and discharged into anti-coagulant free bottle, centrifuged at $3000 \mathrm{~g}$ for ten minutes. The serum obtained was stored at $-20^{\circ} \mathrm{C}$ prior to analysis.

\subsection{Estimation of serum elements and vitamin levels}

The serum concentrations of $\mathrm{Mn}, \mathrm{Se}, \mathrm{Zn}, \mathrm{Cu}, \mathrm{Mo}, \mathrm{Co}, \mathrm{Fe}$, and $\mathrm{Cr}$ were quantified using the Atomic Absorption Spectrometric method. Serum levels of thiamine, riboflavin, niacin, folic acid, pantothenic acid, and vitamins $\mathrm{A}, \mathrm{B}_{6}, \mathrm{C}, \mathrm{D}$ and $\mathrm{E}$, on the other hand were determined using High Performance Liquid Chromatographic technique (HPLC). The HPLC equipment supplied by Waters $₫$ Corporation Milford, Massachusetts USA and Buck Scientific 205 Atomic Absorption (Buck Scientific, East Norwalk, Connecticut, USA) were employed for this purpose.

\subsection{Statistical analysis}

The degree of significant difference among the serum levels of micronutrients for the three groups was determined, by using analysis of variance (ANOVA). A p value of $\leq 0.05$ was considered significant. SPSS package version 15 was used for this purpose.

\section{Results}

When the data obtained from administration of Wistar rats with fake and genuine sildenafil citrate were compared using analysis of variance, results obtained revealed that while vitamins like folic acid and vitamins $\mathrm{A}, \mathrm{C}$, and $\mathrm{E}$ were significantly different, others such as thiamine, niacin, vitamin B12, riboflavin, pyridoxine, pantothenic and vitamin D were not significantly changed as shown in Table 1. On the other hand, results in Table 2 show that although $\mathrm{Se}, \mathrm{Cu}$ and $\mathrm{Zn}$ were significantly different, $\mathrm{Mn}, \mathrm{Fe}, \mathrm{Cr}$, Mo, and Co was not significantly changed. All the animals used for the study survived till the end of the experiment.

Table 1: Serum Concentrations of Vitamins in Rats Dosed With Fake and Genuine Sildenafil Citrate.

\begin{tabular}{llllll} 
& control & $\begin{array}{l}\text { Fake } \\
\text { sildenafil } \\
\text { citrate }\end{array}$ & $\begin{array}{l}\text { Genuine } \\
\text { sildenafil } \\
\text { citrate }\end{array}$ & $\begin{array}{l}\text { F- } \\
\text { value }\end{array}$ & $\begin{array}{l}\text { P- } \\
\text { value }\end{array}$ \\
\hline $\begin{array}{l}\text { Vitamin E } \\
(\mu \mathrm{mol} / \mathrm{L})\end{array}$ & $20.90 \pm 2.12$ & $15.30 \pm 1.46$ & $20.55 \pm 1.07$ & $\begin{array}{l}22.82 \\
5\end{array}$ & $\begin{array}{l}0.011 \\
*\end{array}$ \\
$\begin{array}{l}\text { Vitamin C } \\
(\mathrm{mmol} / \mathrm{L})\end{array}$ & $38.32 \pm 2.53$ & $29.40 \pm 3.45$ & $34.37 \pm 4.02$ & $\begin{array}{l}10.43 \\
0\end{array}$ & $\begin{array}{l}0.001 \\
*\end{array}$ \\
$\begin{array}{l}\text { Vitamin A } \\
(\mu \mathrm{mol} / \mathrm{L})\end{array}$ & $1.42 \pm 0.08$ & $1.06 \pm 0.04$ & $1.25 \pm 0.04$ & 61.40 & 0.005 \\
$\begin{array}{l}\text { Riboflavin } \\
(\mathrm{nmol} / \mathrm{L})\end{array}$ & $219.25 \pm 6.46$ & $203.71 \pm 43.6$ & $215.47 \pm 9.1$ & 0.599 & 0.562 \\
$\begin{array}{l}\text { Folic }(\mathrm{nmol} / \mathrm{L}) \\
\text { Pyridoxine } \\
\text { (nmol/L) }\end{array}$ & $24.29 \pm 4.17$ & $16.76 \pm 2.50$ & $24.39 \pm 1.96$ & 29.76 & 0.000 \\
$\begin{array}{l}\text { Niacin } \\
(\mathrm{nmol} / \mathrm{L})\end{array}$ & $60.62 \pm 2.14$ & $58.47 \pm 2.84$ & $61.94 \pm 2.28$ & 3.111 & 0.074 \\
$\begin{array}{l}\text { Thiamine } \\
(\mathrm{nmol} / \mathrm{L})\end{array}$ & $115.06 \pm 4.66$ & $118.83 \pm 2.81$ & $114.69 \pm 6.3$ & 1.871 & 0.085 \\
$\begin{array}{l}\text { Vitamin D } \\
(\mathrm{nmol} / \mathrm{L})\end{array}$ & $59.91 \pm 7.31$ & $57.92 \pm 5.19$ & $59.38 \pm 2.60$ & 0.441 & 0.652 \\
$\begin{array}{l}\text { Pantothenic } \\
\text { acid }(\mu \mathrm{mol} / \mathrm{L})\end{array}$ & $2.11 \pm 0.02$ & $2.10 \pm 0.01$ & $2.08 \pm 0.05$ & $7 . .274$ & 0.058 \\
$\begin{array}{l}\text { Cyanocobalami } \\
\mathrm{n}()\end{array}$ & $300.84 \pm 13.0$ & $306.44 \pm 9.25$ & $298.63 \pm 8.4$ & 1.283 & 0.306 \\
\hline & 9 & $154.67 \pm 4.26$ & $150.51 \pm 5.7$ & 1.561 & 0.242 \\
\hline
\end{tabular}

Results are expressed as mean \pm standard error of mean. $* \mathrm{P}<0.05$ is significant. $\mathrm{N}=7$.

Table 2: Serum Concentrations of Minerals in Rats Dosed with Fake and Genuine Sildenafil Citrate.

\begin{tabular}{|c|c|c|c|c|c|}
\hline & Control & $\begin{array}{l}\text { Fake sildena- } \\
\text { fil citrate }\end{array}$ & $\begin{array}{l}\text { Genuine } \\
\text { sildenafil } \\
\text { citrate }\end{array}$ & $\begin{array}{l}\mathrm{F}- \\
\text { value }\end{array}$ & $\begin{array}{l}\mathrm{P}- \\
\text { value }\end{array}$ \\
\hline $\begin{array}{l}\text { Se } \\
(\mu \mathrm{mol} / \mathrm{L})\end{array}$ & $0.86 \pm 0.04$ & $0.53 \pm 0.04$ & $0.77 \pm 0.06$ & 78.030 & $0.005^{*}$ \\
\hline $\begin{array}{l}\mathrm{Cu} \\
(\mu \mathrm{mol} / \mathrm{L})\end{array}$ & $18.48 \pm 1.79$ & $20.60 \pm 0.80$ & $21.92 \pm 4.12$ & 3.072 & $0.049 *$ \\
\hline $\begin{array}{l}\mathrm{Zn} \\
(\mu \mathrm{mol} / \mathrm{L})\end{array}$ & $17.46 \pm 3.44$ & $13.22 \pm 1.45$ & $15.21 \pm 1.48$ & 5.015 & $0.021 *$ \\
\hline $\begin{array}{l}\mathrm{Mn} \\
(\mathrm{nmol} / \mathrm{L})\end{array}$ & $148.09 \pm 2.86$ & $150.61 \pm 4.39$ & $153.13 \pm 2.35$ & 3.456 & 0.058 \\
\hline $\begin{array}{l}\mathrm{Fe} \\
(\mu \mathrm{g} / \mathrm{dl})\end{array}$ & $136.71 \pm 6.02$ & $137.22 \pm 3.93$ & $140 / .73 \pm 6.29$ & 1.337 & 0.292 \\
\hline $\begin{array}{l}\text { Mo } \\
(\mathrm{nmol} / \mathrm{L})\end{array}$ & $20.36 \pm 2.04$ & $20.13 \pm 1.80$ & $21.93 \pm 3.07$ & 1.031 & 0.381 \\
\hline $\begin{array}{l}\mathrm{Cr} \\
(\mathrm{nmol} / \mathrm{L})\end{array}$ & $2.01 \pm 0.06$ & $2.05 \pm 0.03$ & $1.98 \pm 0.04$ & 2.351 & 0.129 \\
\hline $\begin{array}{l}\text { Co } \\
\text { (nmol/L) }\end{array}$ & $3.93 \pm 0.15$ & $3.74 \pm 0.17$ & $3.87 \pm 0.16$ & 2.108 & 0.156 \\
\hline
\end{tabular}

Results are expressed as mean \pm standard error of mean. $* \mathrm{P}<0.05$ is significant. $\mathrm{N}=7$.

\section{Discussion}

Micronutrients are essential for health. The significant decreases in the serum levels of minerals and vitamins observed in fake drug administered rats means that while it is already established that fake drug are rarely efficacious, exposure to them may also result in medical conditions associated with micronutrient deficiency. Reports have suggested that many of the medical manifestations associated with fake drugs are dramatic, instantaneous and devastating in nature. A case in point is the incidence involving contamination of heparin by Chinese counterfeiters in 2007 and 2008 that resulted in the death of 149 patients in the USA (Liu et al. 2009, Chika et al. 2011). Another is that of the death of 109 pediatric patients which occurred in Nigeria as a result of exposure to fake paracetamol (Aluko 1994, Erhun et al. 2001).

While such dramatic effects of fake drugs have served as a wakeup call for the authorities to deal with issue of fake drug, in most cases the impact of fake drug may be devastating without being dramatic. $0 \%$ mortality was observed for the rats administered with both fake and genuine sildenafil citrate. In some cases, the devastating effects of fake drug may not be revealed for several months or years. A good example of this is alteration in micronutrient levels; micronutrients are essential biomolecules and elements that play vital physiologic role in the body. While significant decreases may not cause instant dramatic effects, it may initiates many devastating and pathologic manifestations, example of which is the carcinogenic process (Shenkin et al. 2006).

Many of the micronutrients known to play important role in maintaining the genome were significantly altered. Of the four micronutrients that play this role; folate, vitamin $\mathrm{B} 12$, niacin and zinc, only niacin and B12 were not significantly different, zinc and folate were significantly decreased. In addition, Se, which Ferguson et al. (Ferguson et al. 2004) have reported that its low levels of less than $100 \mathrm{ng} / \mathrm{ml}$ was a cause of impaired DNA repair as well as surveillance of oxidative (and other) DNA damage in middle-aged New Zealand men was also significantly decreased. That $\mathrm{Zn}$ and folate depletion will have such effects have been revealed through a study, in which marginal deficiencies in folate, vitamin B12, niacin and zinc impact significantly on spontaneous chromosome damage rate (Fenech 2002, Fenech et al. 2005, Simon et al. 2012).

In a more specific term, a number of processes have been highlighted in which the role of $\mathrm{Zn}$ in genome stability is essential. According to Sharif et al. (2012), Zn plays a critical role in the regulation of DNA repair mechanisms, cell proliferation, differentiation and apoptosis involving the action of various transcriptional factors and DNA or RNA polymerases. Zinc may also affect activities of enzymes in the folate-methionine cycle. Chromoso- 
mal mutations that are frequently encountered in cancer cells, has been linked with dietary insufficiency, optimum folate level especially has been identified to be an essential requirement for DNA repair and synthesis as well as maintenance of genome.

Aside, the possible impact on the DNA and the genome, another implication of these significant decreases is a derailment in the antioxidant functions of the significantly different ones. Selenium and $\mathrm{Zn}$ are cofactors for the enzyme glutathione peroxidase and superoxide dismutase respectively. Other physiologic functions of these micronutrients may be adversely affected. Vitamin E, found in abundant quantity in vegetable oil and seeds such as almonds and peanuts, which acts as lipid-soluble antioxidant in cell membranes, and is also known to be very important for maintenance of cell membrane fluidity was significantly lower in fake drug administered rats (Yachi et al. 2010). Whereas vitamin D, a pleiotropic vitamin-hormone that has impact on classical and nonclassical tissues, that it's primarily sites of action are intestine, bone, and kidneys (Rosen et al. 2012) is not significantly different when the three groups were compared using ANOVA.

Manganese, $\mathrm{Fe}, \mathrm{Cr}$, Mo, Co, riboflavin, thiamine, pyridoxine and pantothenic acid were not significantly different whereas ascorbic acid and vitamin A were significantly different with levels in fake drug administered rats being more significantly lower than either the control or genuine sildenafil citrate dosed rats. Both ascorbic acid and vitamin A are known for antioxidant roles and their depletion may be associated with increase in generation of reactive oxygen species. The fact that fake drug is more common in Africa and Asia, may not be unconnected with regulatory and enforcement systems for medicines, that are known to be weak. These are two sub-regions already encumbered with various social-economic problems. The significant decreases in many of these micronutrients may likely increase disease-burden in resource scarce areas of the world. In addition to these possibilities, WHO has also warned that, "Counterfeit drugs may erode public confidence in health care systems, health care professionals, the suppliers and sellers of genuine drugs, the pharmaceutical industry and national Drug Regulatory Authorities".

While the consequences of counterfeit drugs have been reported to vary widely, various solutions are also being proffered. Some of the solutions will lie in collective involvement, responsibility, and responses of all interested parties: health professionals, drug regulatory authorities, judicial entities, and drug companies at both national and international levels. More importantly, there will also be the need to strengthen drug regulatory authorities, which should not only be responsible for improving drug standards, but also provide effective recognition of counterfeit drugs and assist other agencies in stopping their trade. Such interventions are needful in those countries that have either no drug regulation at all or have an impaired or corrupted system. Aside this, enactment and enforcement of new laws for prohibiting counterfeit drugs is also very important. Fake anti-malaria agents and anti-infective drugs have regional distribution, with the bulk found in the developing world, but the fake sildenafil citrate used for this study and whose administration to male Wistar rats resulted in significant decreases in the levels of a number of these micronutrients is global in scope in terms of distribution. This means that addressing the problem of manufacture, sale and distribution of fake sildenafil citrate will entail an approach of global proportion such as the International Medical Products Anti-Counterfeiting Taskforce (IMPACT), a global initiative created in 2006 by the World Health Organization (WHO 2006, IMPACT 2007)

\section{References}

[1] Aluko SO (1994) Death for Sale: A case study of drug poisoning and deaths in Nigeria. Social Science and Medicine 38, 97. http://dx.doi.org/10.1016/0277-9536 (94)90304-2.

[2] Chika A, Bello SO, Jimoh AO \& Umar MT (2011) the Menace of Fake Drugs: Consequences, Causes and Possible Solutions. Research Journal Medical Sciences 5, 257-261. http://dx.doi.org/10.3923/rjmsci.2011.257.261.
[3] Erhun WO, Babalola OO \& Erhun MO (2001) Drug Regulation and Control in Nigeria: The Challenge of Counterfeit Drugs. Journal of Health \& Population in Developing Countries 4, 23-34.

[4] Fenech M (2002) Micronutrients and genomic stability: a new paradigm for recommended dietary allowances (RDAs). Food \& Chemical Toxicology 40, 1113-7. http://dx.doi.org/10.1016/S0278-6915 (02)00028-5.

[5] Fenech M, Baghurst P, Luderer W, Turner J, Record S, Ceppi M, et al (2005) Low intake of calcium, folate, nicotinic acid, vitamin E, retinol, beta-carotene and high intake of pantothenic acid, biotin and riboflavin are significantly associated with increased genome instability-results from a dietary intake and micronucleus index survey in South Australia. Carcinogenesis 26, 991-9. http://dx.doi.org/10.1093/carcin/bgi042.

[6] Ferguson LR. Philpott M \& Karunasinghe N (2004) Dietary cancer and prevention using antimutagens. Toxicology 198, 147-59. http://dx.doi.org/10.1016/j.tox.2004.01.035.

[7] Fibbi B, Morelli A, Marini M, Zhang XH, Mancina R, Vignozzi L, et al (2008) Atorvastatin but not elocalcitol increases sildenafil responsiveness in spontaneously hypertensive rats by regulating the RhoA/ROCK pathway. Journal of Andrology 29, 70-84. http://dx.doi.org/10.2164/jandrol.107.003152.

[8] Gautam CS, A Utreja A \& Singal GL (2009) Spurious and counterfeit drugs: a growing industry in the developing world. Postgraduate Medical Journal 85, 251-256. http://dx.doi.org/10.1136/pgmj.2008.073213.

[9] International Medical Products Anti-Counterfeiting Taskforce (2007) Principles and Elements for National Legislation against Counterfeit Medical Products; IMPACT General Meeting Lisbon; 1-13.

[10]Jackson G, Patel S \& Khan S (2012) Assessing the Problem of Counterfeit Medications in the United Kingdom. International Journal of Clinical Practice 66, 241-250. http://dx.doi.org/10.1111/j.1742 1241.2011.02826.x.

[11]Liu H, Zhang Z \& LInhardt RJ (2009) Lessons learned from the contamination of heparin. Natural Products Reports 26, 313-21. http://dx.doi.org/10.1039/b819896a.

[12]Mali DK, Mitkare SS \& Moon RS (2011). Anti-counterfeit packaging in pharma industry: review. International Journal Pharmacy Pharmaceutical Science 3, 46.

[13]Rosen CJ, Adams JS, Bikle DD, Black DM, Demay MB, Manson JE, Murad MH \& Kovacs CS (2012) the nonskeletal effects of vitamin D: an endocrine society scientific statement. Endocrine Review 33, 456492. http://dx.doi.org/10.1210/er.2012-1000.

[14] Sharif R, Thomas P, Zalewski P \& Fenech M (2012) the role of zinc in genomic stability. Mutation Research 733, 111-21. http://dx.doi.org/10.1016/j.mrfmmm.2011.08.009.

[15] Shenkin A, Baines M, Fell G \& Lyon TDG (2006) Vitamins and trace elements, in: Burtis CA, Ashwood ER, Bruns DE, editors. Tietz textbook of Clinical Chemistry and Molecular Diagnostics. Missouri: Saunders 1075-1164

[16]Simon KW, Ma H, Dombkowski AA \& Cabelof DC (2012) Aging alters folate homeostasis and DNA damage response in colon. Mechanism of Ageing and Development 133, 75-82. http://dx.doi.org/10.1016/j.mad.2012.01.003.

[17]WHO Report (2006) International medical products anti-counterfiting taskforce?

[18] Yachi R, Igarashi O \& Chikako Kiyose C (2010) Protective Effects of Vitamin E Analogs against Carbon Tetrachloride-Induced Fatty Liver in Rats. Journal Clinical Biochemistry Nutrition 47, 148-154. http://dx.doi.org/10.3164/jcbn.10-35. 